\title{
Privately-Owned Public Space for Public Use
}

\author{
Achmad Delianur Nasution, Wahyuni Zahrah \\ Department of Architecture, Faculty of Engineering, \\ University of Sumatera Utara \\ aan.nasution@gmail.com
}

\begin{abstract}
The study investigated the using of privately-owned public space (POPS) in two gated communities in Medan, Indonesia. The activities of people during the weekend and the physical setting of the POPS were recorded through observation and visual survey. The research found that most of the visitors were not satisfied with the public open space, but they used it intensively. The study indicated that the better quality public open space was more livable compared to the poor quality. Since the visitors in the two public open spaces were mostly people who live outside the gated community, the privateowned public space contributed to public life.
\end{abstract}

Keywords: privately-owned public space; gated community; Medan.

eISSN: 2398-4279 @ 2017. The Authors. Published for AMER ABRA by e-International Publishing House, Ltd., UK. This is an open access article under the CC BY-NC-ND license (http://creativecommons.org/licenses/by-ncnd/4.0/). Peer-review under responsibility of AMER (Association of Malaysian Environment-Behaviour Researchers), ABRA (Association of Behavioural Researchers on Asians) and cE-Bs (Centre for EnvironmentBehaviour Studies), Faculty of Architecture, Planning \& Surveying, UniversitiTeknologi MARA, Malaysia.

https://doi.org/10.21834/ajqol.v2i7.60 


\subsection{Introduction}

\subsection{Background}

What is the main characteristic of the capital cities in Indonesia? Privatized public space! The growth of the malls, cafes, theme park, and gated community is very fast. The middle up income people needs, that avoids the unification with the poor, has made the developments getting higher compared to free-access public open space (POS). Yet the POS gives a positive influence on the people's quality of life (Nasution and Zahrah, 2013). In the other hand, the privatized public open space still provides a positive contribution to community quality of life (QOL) by generating a livable public life (Nasution and Zahrah, 2012).

Besides the urban-scale POS, there are still a few neighborhood-scale POS in Medan, both in a planned and unplanned settlement. The low-quality neighborhood-scale POS is more livable than those of the urban-scale and gives a significant role to the community QOL (Nasution and Zahrah, 2013). Most of the planned settlement in Medan is a gated community. When the public place is managed and owned by a private institution, it is categorized as a privately owned public space (POPS).

\subsection{The objective}

The opinion about the 'handicapped' of privatized public space, still in debates. The issue includes the 'filtering' of the users by controlling the access. How high the 'isolation grade' of it in relation with the using of the public space? Does the control of the settlement relate to the life of POS? Does the middle up income people need and use the open space in their gated-environment, which separated with the outside community?

The study aim is to identify the life of the POS in a gated community. The study is necessary to get some description of the role of this kind of POS in public life under the fact that the growth of privatized public space is higher than the free-access POS. The life of the POS in a gated community can be the indicator of how intensive the community use it, and next, how high the users take the advantage of it to their QOL.

\subsection{Literature Review}

\subsection{Successful Public open space}

Public open space is a place for the community to gather and doing many kinds of activities freely. The parameters used to assess the successful of public space relate to physical and non-physical factors. Whyte (1985) said that the ability of space in accommodating various social activities is one indicator of a pleasant POS. Gehl (1987) argued that a successful POS should accommodate a larger recreational-optional than necessary activities, and, a high-quality environment supports it. Among various approaches to determining a 
successful public space, Project for Public Spaces proposes a comprehensive parameter. PPS has identified that successful ones have four fundamental qualities. The first, they are accessible. The second, people are engaged in activities there. The third, the place is comfortable and has a good image. The fourth, it is a sociable place: one where people meet each other and take people when they come to visit (www.pps.org).

\subsection{Gated Community in Indonesia}

The gated community rises from a 'culture of fear' of the middle up income urban people to many criminal threats. The condition then forces a segregated community (Boyers and Manzi, 2006). Blakely and Snyder (1998) define gated community as "residential areas with restricted access that makes public spaces private. Access is controlled by physical barriers, walled or fenced perimeters, and gated or guarded entrances."

Physically, most of the gated communities in Indonesia always have a gate, but not all of them enforce a high security. In several cases, even there is no security officer (Leisch, 2002). When Blakely and Snyder (1998) classify gated community in the US to the zones of lifestyle, prestige, and safety, a gated community in Indonesia is the mix of the three. From the socio-economic aspect, the security issue becomes the concern of the development, but the prestige and the lifestyle become the most important (Leisch, 2002).

Public open space in a gated community is one of the facilities for residents for their social interaction needs (Aulia and Ismail, 2013). When the community outside the gate can access the public services, it becomes a privately-owned public space (POPS). The term 'POPS' is first known on 1961 when the New York City Government involving the private institution to improve the accessible public spaces, mostly in a dense urban area (Luk, 2009). Many studies about privatized public space argue that the area decreases the 'publicness' due to the access and activity control. As a consequence, it prevents the opportunity for urban people to work together as a community, to solve the problem mutually, to gain the inspiration from the difference (Feldman, 2007)

The positive opinion about privatized public space relates to its better management and quality (Melik, 2009). A study by Nasution and Zahrah (2011) for privatized POS in Medan indicates that the place gives a contribution to the public life in the city.

\subsection{Methodology}

The objects of the study are public open spaces in two biggest gated communities in Medan, namely Cemara Asri and Taman Setiabudi Indah (Tasbi). The parameter in determining the life of POS needs both the physical and perception data. The physical data was collected through a visual survey to record the elements of the plan, design, and activities occur. Based on the digital map of Medan City, the condition of the POPS is updated and redrawn. The drawing shows the design elements, such as trees and other greenery, access point, the circulation path, outdoor seating, parking lot, the street vendor. 
Furthermore, the observers recorded all activities in the setting, by using the behavioral mapping method.

The study collected the perception data through an interview that based on a questionnaire. There was a set question about the socio-economic background, the frequency of visits, the perception of POS factors, such as linkage and access, comfort and image, uses and activities and sociability. The respondents were people that were doing their activities in POSs. They were chosen randomly in the access point of the POS.

The study analyzes the life of POS by describing the quality of POS' actual physical condition that refers to the relevant theories. The satisfaction level of the users' perception was indicated by the mean scores of each variable. The score below three indicates the low pleasant while the upper one shows the higher.

\subsection{Results and Discussions}

\subsection{Respondent characteristics}

The respondents in the two POPSs have a similar characteristic. The most of them were lower than 30 years old, men, having a private vehicle, living more than $1 \mathrm{~km}$ outside the gated community (Table 1.)

Table 1. Respondents' characteristics

\begin{tabular}{lll}
\hline & Tasbi & Cemara Asri \\
\hline Sex & Female 33\%; Male 67\% & Female 42,5\%; Male 57.5\% \\
\hline Age & $10-2036 \% ;$ & $10-2012.6 \% ;$ \\
& $21-3020 \% ;$ & $21-3052.5 \% ;$ \\
& $31-4027 \%$ & $31-402.5 \%$ \\
\hline Vehicle & Motorcycle 37\%; & Motorcycle 40\%; \\
ownership & car 36\% & car 17.5\% \\
\hline Monthly & $<1$ M IDR 57\%; & $<1$ M IDR 0\%; \\
expenses & $2.5-5$ M IDR 30\% & $2.5-5$ M IDR 40\% \\
\hline Distance & $<1 \mathrm{~km} \mathrm{17 \% ;}$ & $<1 \mathrm{~km} \mathrm{17.5 \% ;}$ \\
from home & $>1 \mathrm{~km} \mathrm{83 \%}$ & $>1 \mathrm{~km} \mathrm{82.5 \%}$ \\
\hline
\end{tabular}

\subsection{Access and Linkage}

As middle up income people settlement, Cemara Asri, and Tasbi have the common natures of a gated community, such as wall and fence that separates them from the outside community. However, there is no a high control about who are entering the complex when we can just pass it slowly without any interview about what we aim. The fact confirms what Leisch (2002) said about the 'speciality' of the gated community in Indonesia. Thus, anyone can use any facilities in the two gated communities 'without an over-control'.

The POS in Tasbi is a square when in Cemara Asri is a park. Cemara Asri Park has a better visual and structural linkage when it takes place at the end of the main access road, 
so anyone can see it from the gate. The conditions make Cemara Asri more 'readable'. Furthermore, the distance is in walkable range. In contrast, Tasbi Square, though structurally takes place in the center of the block and connected to the other facilities, cannot be read so easily (Fig. 1).

There is no high-quality pedestrian path in the two POPS. In Tasbi the path is truncated at the end of the main boulevard; not continuous to the square. The pedestrian path in Cemara Asri is a space between the front edge of commercial buildings row and the main boulevard. The distance from the gate is shorter than Tasbi; it is more convenient for the pedestrian to walk (Fig. 1). There is a slight number of the visitors accessing the POPS by walk. Most of them use their private vehicle, both motorcycle, and car.

The visitors of Cemara Asri perceived the access and linkage as quite good. In contrast, the visitors of Tasbi were not satisfied, with the average scores under 3 (Table 2). The facts confirm the past studies that the quality of POS relates to the community satisfaction (Nasution dan Zahrah, 2013).

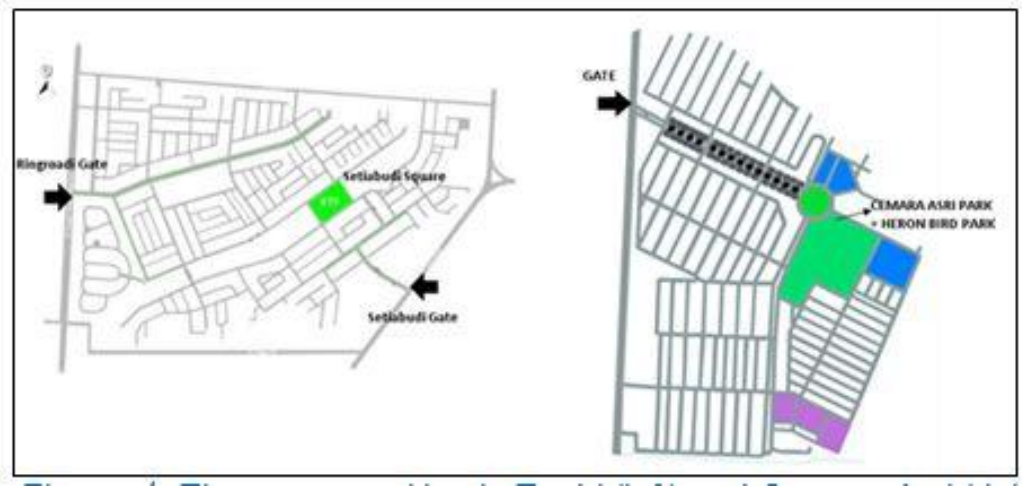

Figure. 1. The gates position in Tasbi (left) and Cemara Asri (right)

\subsection{Comfort and Image}

The POS of Tasbi is a square of about one hectare without an adequate facility. There is no sitting area, so the visitors sit everywhere they can: in a grass field, on the trees' roots or on a motorcycle that put on the edge of the field. However, there are many trees along the square's periphery and make the square green and shady. There is no 'attraction' but the sports exercising (mostly karate and football) that always take place in the square almost every day.

The different atmosphere occurs in Cemara Asri. Many trees shade along the circlecirculation path. Inside the garden, there is a grass field with circle pedestrian path. There is an 'arch-pergola-gate' as a sign for the entry point. On the east side, there is Birds Park, a wetland as the habitat of heron bird (Ciconiidae family). It makes Cemara Asri Park looks 
more attractive than Tasbi. However, similar to the Tasbi Square, there is no a convenience sitting area here. So, the visitors sit on the bank of the pond or just standing while watching the bird.

The community perception of comfort and image in Cemara Asri is better than Tasbi since the park more attractive, cleaner and greener (Table 2). The fact is equal with the study of how good image park makes higher value to the residents (Shukur, Othman, and Nawawi, 2010).

Table 2. The satisfaction with the successful indicators of POS

\begin{tabular}{lll}
\hline & Tasbi & Cemara Asri \\
\hline ACCESS AND LINKAGE & 3.27 & 3.45 \\
\hline Continuity & 3.10 & 3.18 \\
\hline Proximity & 2.83 & 3.40 \\
\hline Connected & 3.27 & 3.33 \\
\hline Readable & 2.33 & 3.45 \\
\hline Walkable & 2.25 & 3.65 \\
\hline Convenient & 2.83 & 3.30 \\
\hline Accessible & & \\
\hline COMFORT AND IMAGE & 2.65 & 3.43 \\
\hline Safe & 2.30 & 3.28 \\
\hline Clean & 3.20 & 3.45 \\
\hline Green & 2.33 & 3.45 \\
\hline Walkable & 2.37 & 3.30 \\
\hline Sittable & 2.55 & 3.48 \\
\hline Attractive & & \\
\hline USES AND ACTIVITIES & 2.70 & 3.40 \\
\hline Fun & 2.77 \\
\hline Active & 2.73 \\
\hline Sustainability & 3.48 \\
\hline Vital & 3.33 \\
\hline Celebratory & 2.17 & 3.33 \\
\hline SOCIABILITY & 2.80 & \\
\hline Interactive & & \\
\hline Diverse & 2.77 & 3.34 \\
\hline Friendly & 2.77 & 3.33 \\
\hline Welcoming & 2.55 \\
\hline
\end{tabular}

\subsection{Uses and Activities}

The visitors of Tasbi square are mostly teenagers under 20 (36\%). The most activities are doing sports, such as karate and football. The activities can be classified as necessary activities since the sports club runs a periodical exercise. The other activities are sitting or standing while talking and watching the game. Some visitors are eating in the street vendor at the side of the grass field. There are some optional activities, such as an individual sport or just relaxing while enjoying the environment, but very rarely. Besides the day-to-day operation, there is the special event in the square, but in a rare frequency. 
The visitors of Cemara Asri are mostly citizens of 21-30 years old (52.5\%). The park mainly used over the weekend, on Saturday and Sunday, from $6.00-10.00$ in the morning and $16.00-18.00$ in the afternoon. Sports exercising are the primary activities $(48 \%)$. The others are relaxation (38\%) and social interaction (20\%). The term "recreation" relate to a relax-informal activity, such as sitting or walking around while eating or talking with family and friends. Though there is no bench or sitting facility, there are many of people come. So the park looks fun, vital and active, more than the Tasbi Square does (Fig. 2). The heronwetland-park also makes the park special. The other recreational activity is eating in the street vendor area. There is much of street vendor selling various food and fashion stuff (Fig. 2).

Both the Tasbi square and Cemara Asri never accommodate political activity. Many scholars argue that the management of the privatized public spaces always controls this kind of activity. However, the life of the two squares is active, with various visitors' socioeconomic background, ages, and different activities.

Table 3. The social activity

\begin{tabular}{lcccc}
\hline The questions & \multicolumn{2}{c}{ Tasbi } & \multicolumn{2}{c}{ Cemara Asri } \\
\cline { 2 - 5 } & Yes & No & Yes & No \\
\hline $\begin{array}{l}\text { Do the POS influence your } \\
\text { social interaction quality? }\end{array}$ & $90 \%$ & $10 \%$ & $82 \%$ & $18 \%$ \\
\hline $\begin{array}{l}\text { Have you ever made a social } \\
\text { interaction? }\end{array}$ & $80 \%$ & $20 \%$ & $63 \%$ & $37 \%$ \\
\hline $\begin{array}{l}\text { Have you ever say hello or } \\
\text { introduce yourself to the } \\
\text { strangers? }\end{array}$ & $83 \%$ & $17 \%$ & $65 \%$ & $35 \%$ \\
\hline $\begin{array}{l}\text { Who do you with when coming } \\
\text { to the POS? }\end{array}$ & $\begin{array}{l}\text { Alone 7\% } \\
\text { With partner 13\% } \\
\text { With family/friends 80\% }\end{array}$ & $\begin{array}{l}\text { Alone 7. } \% \\
\text { With partner 12.5\% } \\
\text { With family/friends 80\% }\end{array}$ \\
\hline
\end{tabular}

\subsection{Sociability}

One of the sociability aspects of the two POPS is indicated by a low-security check in the gates. It makes the POPS 'welcoming'. However, there are more visitors in Cemara Asri compared to Tasbi. The social background of Cemara Asri users is also more diverse than Tasbi. The visitors, though mostly are Chinese, are mixed in the POS. The fact shows a unique feature since the gap between Chinese and 'pribumi' (the Indonesian term for indigenous people) has been becoming problems in Indonesia for hundreds of years (Leisch, 2002). The condition is strengthening by the fact that most of the visitors ever performed a social interaction. They come in groups, and ever 'said hello' to the strangers in the park (Table 3). The study finds that most of the visitors in the two POSs are not the residents, but the people who live outside the gated community. The fact indicates the POS is more lived by community outside. 


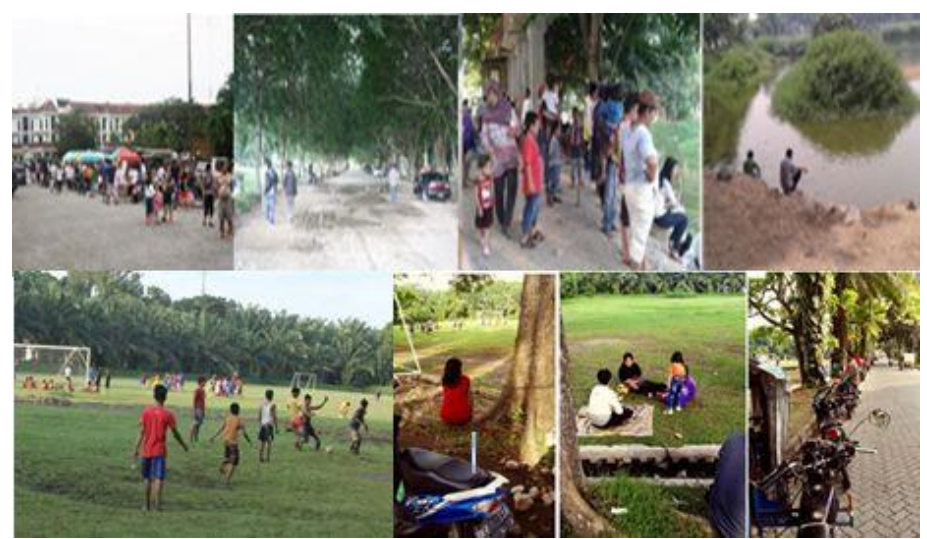

Figure 2. Public life in Cemara Asri Park (Top) and Setiabudi Square (Bottom)

\subsection{Conclusion}

The research confirms the study carried out by Grobelšek (2012) that POPS can be a complement to the whole public space in the city. The public life shows that POPSs give a positive contribution to fulfilling the community needs for a communal space. Since the POPSs open the access for the community outside, they have given an opportunity for a diverse community to mix. The study indicates that the POPSs role as a kind of a 'unification media'. The study points out that only a small portion of residents involved in the POPSs life. Further research is needed to determine their perception about the POPSs. The research indicates that, with the financial and management potency of the private institution, the gated community can contribute many more high-quality POPSs. The government must become a facilitator to improve the participation of the private institution.

\section{Acknowledgement}

The authors would like to give appreciation to those involved in this study include all students in 2012 Urban and Housing Research Class, Department of Architecture, Universitas Sumatera Utara, individuals, groups and another related body.

\section{References}

Aulia, Dwira, and Ismail, Abdul Majid. (2013). Residential Satisfaction of Middle Income Population: Medan city. Procedia - Social and Behavioral Sciences 105 ( 2013 ) 674 - 683

Blakely, E.J., and M.G. Snyder. (1998). Separate places: Crime and security in gated communities." In: M. Felson 
and R.B. Peiser (eds.), Reducing crime through real estate development and management, pp. 53-70. Washington, D.C.: Urban Land Institute.

Feldman, Rachel. (2007). The Loss of Public Space in America: A Suburban Case Study. http://www.fandm.edu/uploads/media_items/junto-0809-feldman.original.pdf

Gehl, Jan. (2002). Public Space and Public Life City of Adelaide: 2002. City of Adelaide, Adelaide

Grobelšek, Liljana Jankovič. (2012). Private space open to the public as an addition to the urban public space network. Urbani izziv, volume 23, no. 1, 2012.

Leisch, Harald Pergamon. (2002) Gated communities in Indonesia. www.elsevier.com/locate/cities PII: S02642751(02)00042-2

Luk W.I.. (2009). Privately owned public space in Hong Kong and New York: The urban and spatial influence of the policy. The 4th International Conference of the International Forum on Urbanism (IFoU)2009 Amsterdam/Delft The New Urban Question - Urbanism beyond Neo-Liberalism 697

Melik, RV; Aalst, IV, Weesep, JV (2009), The private sector and public space in Dutch city centres, Cities, 26 (2009) 202-209

Nasution, Achmad Delianur Nasution and Zahrah, Wahyuni. (2013). Neighborhood Open Space and Quality of Life in Low-Income Settlement: Rahmadsyah Square Case Study, Medan, Indonesia. HABITechno International Seminar - Innovation Housing and Settlement Technology. Bandung : Institut Teknologi Bandung.

Shukur, Farahwaheeda, Othman, Noriah and Nawawi, Abdul Hadi. (2012). The Values of Parks to the House Residents. Procedia - Social and Behavioral Sciences. Volume 49, 2012, Pages 350-359

Project for Publis Space . PPS. (2009). What Makes a Successful Place?http://www.pps.org/reference/grplacefeat/ Whyte, William H. (1985). The Social Life of Small Urban Space. Washington DC: The Conservation Foundation 